\title{
Pharmacokinetics and Tissue Residue Study of Levofloxacin Following Multiple Dose Intramuscular Administration in Poultry
}

\author{
Preeti Bisht, A.H. Ahmad, Alok Mishra and Sankalp Sharma*
}

Department of Veterinary Pharmacology and Toxicology, College of Veterinary and Animal Sciences, G.B.P.U.A \&T. Pantnagar, India

*Corresponding author

\section{A B S T R A C T}

\section{Keywords}

Levofloxacin, Pharmacokinetics, HPLC, Tissue residues, Poultry

Article Info

Accepted:

20 June 2018

Available Online:

10 July 2018
The present study was undertaken to investigate the pharmacokinetics and tissue residue study of levofloxacin @ $10.0 \mathrm{mg} \cdot \mathrm{kg}^{-1}$ in poultry $(n=16)$ following multiple (5) dose intramuscular (i.m.) administration. The concentration of levofloxacin in plasma and tissue of these animals were analysed by HPLC. Following multiple dose i.m. administration volume of distribution, clearance, AUC and elimination half-life after first dose was $5925.34 \mathrm{ml} . \mathrm{kg}^{-1}, 1401.3 \mathrm{ml} . \mathrm{h}^{-1} \cdot \mathrm{kg}^{-1}, 7.32$ h. $\mu \mathrm{g} . \mathrm{ml}^{-1}$ and $2.97 \mathrm{~h}$, respectively and $5193.88 \mathrm{ml} . \mathrm{kg}^{-1}, 1663.16 \mathrm{ml} \cdot \mathrm{h}^{-1} \cdot \mathrm{kg}^{-1}, 6.42 \mathrm{~h} . \mu \mathrm{g} . \mathrm{ml}^{-1}$ and $2.30 \mathrm{~h}$ after the last dose. Residue of levofloxacin was present in kidney, liver and muscle upto $72 \mathrm{~h}$ post administration of levofloxacin with highest concentration of $0.14 \mu \mathrm{g} \cdot \mathrm{g}^{-1}$ in kidney. The limit of detection in tissue was $0.02 \mu \cdot \mathrm{g}^{-1}$.

\section{Introduction}

Levofloxacin, a second-generation fluoroquinolone, possesses excellent activity against Gram-positive, Gram-negative and anaerobic bacteria (Davis and Bryson, 1994; North et al., 1998). Compared to other fluoroquinolones, ofloxacin and ciprofloxacin, it also has more pronounced bactericidal activity against organisms such as Pseudomonas, Enterobacteriaceae and Klebsiella (Klesel et al., 1995). Levofloxacin is $100 \%$ available after oral administration (Chien et al., 1997). The drug distributes well to target body tissues and fluids in the respiratory tract, skin, urine and prostrate and its uptake by cells makes it suitable for use against intracellular pathogens (Langtry and Lamb, 1998). However, it penetrates poorly into the CNS. Levofloxacin is metabolized in the liver to demethyl-levofloxacin and levofloxacin $N$-oxide. About $80 \%$ of a dose is found in the urine as unchanged drug and $\leq 5 \%$ as inactive metabolites (Langtry and Lamb, 1998). The pharmacokinetics of levofloxacin has been investigated in humans (Verho et al., 1996; Amsden et al., 1999; Chulavatnatol et al., 1999; Gascon et al., 2000), rabbits (Mochizuki et al., 1994; Destache et al., 2001), rats (Ito et al., 1999) and guinea pigs 
(Edelstein et al., 1996). However, there is no information available on the multiple dose kinetics of levofloxacin in poultry. The ever increasing use of quinolones, fluoroquinolones in poultry industry has caused their residual deposition in the poultry products resulting in the drug resistant bacteria. It has become a matter of foremost importance to screen the poultry birds of these residual antibiotics, down to the safer MRL's (Maximum Residue Limits). The present study was undertaken to determine the pharmacokinetics and tissue residue study of levofloxacin in poultry after multiple dose kinetics.

\section{Materials and Methods}

The pharmacokinetic and tissue residue study of levofloxacin was conducted in 16 poultry birds with an average weight of $1.0 \pm 0.5 \mathrm{~kg}$. Levomac ${ }^{\circledR}$ (Levofloxacin hemihydrate infusion $0.5 \%$ ) obtained from Macleods Pharm. Ltd. Ahmadabad was injected as multiple (5) dose i.m. at a dose rate of $10 \mathrm{mg} . \mathrm{kg}^{-1}$ for 5 days at $24 \mathrm{~h}$ interval in poultry birds. On $2^{\text {nd }}, 3^{\text {rd }}$ and $4^{\text {th }}$ days of drug administration, blood was collected by left and right brachial veins or from jugular vein immediately prior to drug administration and at 15 and $30 \mathrm{~min}$ post administration. On $1^{\text {st }}$ and $5^{\text {th }}$ day of drug administration, blood samples were collected at $0,5,10,15$ and 30 $\min \& 1,2,4,8,12$ and $24 \mathrm{~h}$ following levofloxacin administration. Plasma was separated and stored at $-30 \mathrm{C}$ and analyzed by high-performance liquid chromatography (HPLC). All samples were analyzed within one week. The plasma proteins were removed via methanol precipitation; $200 \mu \mathrm{l}$ plasma were mixed with $400 \mu \mathrm{l}$ methanol and vigorously shaken. The precipitated proteins were removed via centrifugation at $12000 \times \mathrm{g}$ for 5min. Subsequently, $20 \mu \mathrm{l}$ of the supernatant were injected into the column. For tissue residue study four birds each were sacrificed at 24, 48, 72 and $96 \mathrm{~h}$ post treatment.
Blood samples were collected immediately prior to sacrifice. A postmortem examination was performed and samples of liver, kidney and muscle were collected frozen and stored at $-40^{\circ} \mathrm{C}$ until analyzed. Drug extraction of levofloxacin from tissues was carried out by the method as described by Garcia-Ovando et al., (1997). 4gm of thawed tissue with double amount of acetonitrile homogenize, triturated and was subjected to sonication at 10 amplitude microns for 30 secs, with a pause of 5 seconds (a total of 15 cycles) by using ultrasonic tissue disintegration and centrifuged at 12000 for $15 \mathrm{~min}$ and supernatant dried at $60^{\circ} \mathrm{C}$.

Clean up process of levofloxacin was done by the technique described by Telling and Sissons (1977) with certain modifications carried out using solid- phase extraction $\mathrm{C}_{18}$ cartridges. The dried eluate was reconstituted in $2 \mathrm{ml}$ of acetonitrile and loaded onto the conditioned $\mathrm{C}_{18}$ cartridges and allowed to pass through vacuum $(20 \mathrm{mmHg})$. The cartridges were washed with $2 \mathrm{ml}$ of acetonitrile. The eluate which was obtained after loading of cartridges was filtered through $0.22 \mu \mathrm{m}$ filter paper. 20 $\mu l$ of the sample thus obtained was injected into HPLC system for analysis. The solvents used during the chromatographic analysis of the drug were HPLC grade. The mobile phase consisted of water $(80 \%)$ and acetonitrile (20\%) with $0.3 \%$ of triethylamine and $\mathrm{pH}$ adjusted to 3.3 with phosphoric acid, with a flow rate of $0.7 \mathrm{ml} / \mathrm{min}$ to be detected at UV wavelength of $295 \mathrm{~nm}$. The calibration curves of plasma were prepared with different concentrations between 0.025 and $10 \mu \mathrm{g} / \mathrm{ml}$ using blank poultry plasma. Pharmacokinetic analysis of plasma levofloxacin concentration versus time data was conducted by using WinNonLin Professional version 5.3 software package (Pharsight Corporation, Mountain View, California). The plasma concentrationtime relationship was best estimated as a one compartment model for i.m. $\mathrm{Cp}^{(\mathrm{t})}=\mathrm{Be}^{-\mathrm{t}}$. 


\section{Results and Discussion}

Clinical examination of all animals before and after each trial did not reveal any abnormalities. No adverse reactions were observed after the multiple-dose i.m. administration of levofloxacin in the animals studied. A one-compartment model best represented the plasma concentration versus time data after i.m. administration of levofloxacin in poultry. The mean plasma concentration-time profiles of levofloxacin following multiple i.m. administrations of $10 \mathrm{mg} / \mathrm{kg}$ b.wt after first and last dose are presented graphically in Figure 1. After first and last dose mean \pm SD values of pharmacokinetic parameters estimated from the curve fitting are shown in Table 1. Tissue residue concentration of levofloxacin $\left(\mu \mathrm{g} \cdot \mathrm{g}^{-1}\right)$ with their means following multiple (5) dose $\left(10 \mathrm{mg} . \mathrm{kg}^{-1}\right)$ i.m. administration is depicted in Table 2. The peak plasma concentration of levofloxacin was observed to be 1.42 and 1.50 $\mu \mathrm{g} \cdot \mathrm{ml}^{-1}$ at $30 \mathrm{~min}$ after the first and last dose respectively. Thereafter, the plasma drug concentration decreased slowly to a minimum of 0.07 and $0.06 \mu \mathrm{g} . \mathrm{ml}^{-1}$ of first and last dose respectively. The elimination half-life
( $\left.\mathrm{K}_{10 \_} \mathrm{HL}\right)$ after first and last dose of multiple dose study were $2.97 \mathrm{~h}$ and $2.30 \mathrm{~h}$ respectively. The volume of distribution and clearance of levofloxacin were estimated to be $5925.34 \mathrm{~mL} \cdot \mathrm{kg}^{-1}$ and $1401.31 \mathrm{ml} \cdot \mathrm{h}^{-1} \cdot \mathrm{kg}^{-1}$ respectively after first dose and 5193.88 $\mathrm{mL} \cdot \mathrm{kg}^{-1}$ and $1663.16 \mathrm{ml} \cdot \mathrm{h}^{-1} \cdot \mathrm{kg}^{-1}$ after last dose. The mean area under curve (AUC) after first and last dose were $7.23 \pm 0.19$ h. g.mL ${ }^{-1}$. and $6.42 \pm 0.34$ h. g.mL ${ }^{-1}$ respectively. In the present study, it was observed that following multiple (5) dose i.m. administration in poultry, the levofloxacin in various tissues was high. The maximum residual concentration of levofloxacin was observed in kidney $\left(0.14 \mu \mathrm{g} \cdot \mathrm{g}^{-1}\right)$ following multiple (5) dose i.m. administration in poultry after $24 \mathrm{hr}$ of last dose, which is comparatively higher than that of sarafloxacin $\left(0.08 \mu \mathrm{g} . \mathrm{g}^{-1}\right.$; WHO, 1999) and lower than $0.3 \mu \mathrm{g} \cdot \mathrm{g}^{-1}$ of flumequine (WHO, 2006). In liver the residual concentration of levofloxacin in the preent study was found to be $0.05 \mu \mathrm{g} . \mathrm{g}^{-1}$ which is less than that reported for sarafloxacin $(0.08 \mu \mathrm{g}$. $\mathrm{g}^{-1}$; WHO, 1999), and in muscles high concentration of levofloxacin was found as compared to $0.01 \mu \mathrm{g} \cdot \mathrm{g}^{-1}$ of sarafloxacin (WHO, 1999).

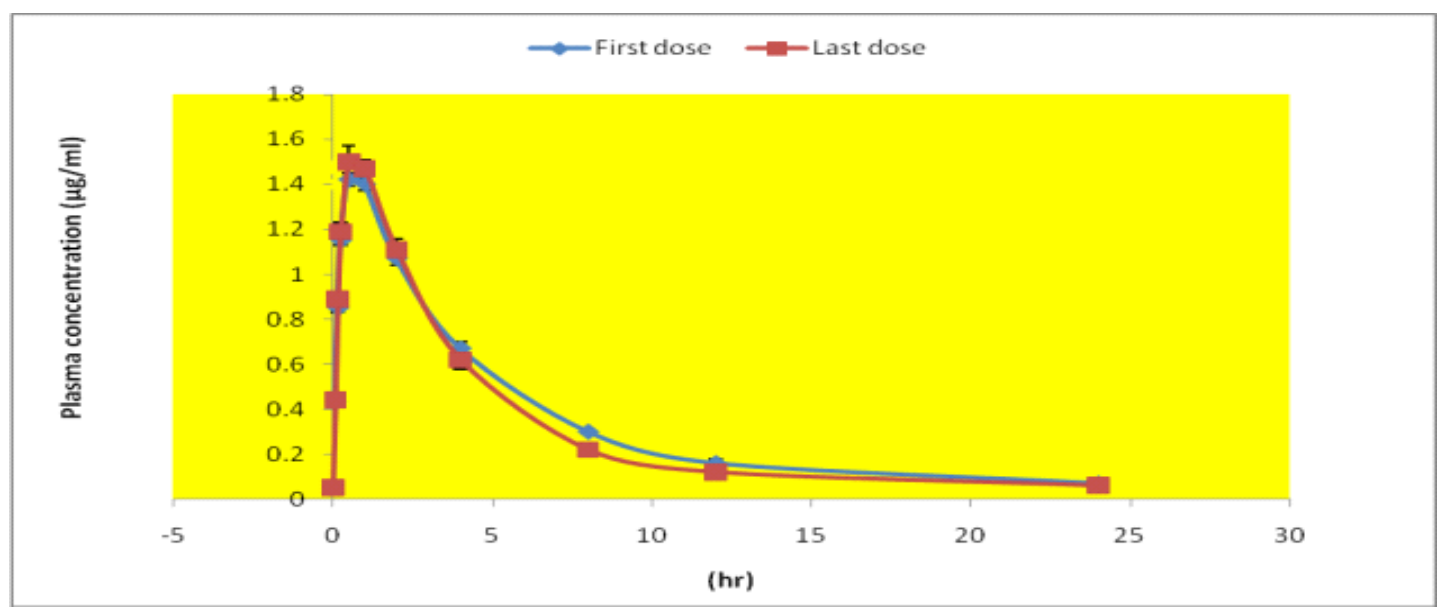

Fig.1 Plasma concentration ( $\mu \mathrm{g} \cdot \mathrm{ml}^{-1}$ ) of levofloxacin (Mean \pm S.E.) after first and last dose following multiple (5) dose $\left(10 \mathrm{mg} \cdot \mathrm{kg}^{-1}\right)$ intramuscular administration in poultry $(\mathrm{n}=16)$ 
Table.1 Pharmacokinetic parameters of levofloxacin in plasma following multiple (5) dose $\left(10 \mathrm{mg} \cdot \mathrm{kg}^{-1}\right)$ intramuscular administration in poultry $(\mathrm{n}=16)$

\begin{tabular}{|c|c|c|c|}
\hline \multirow{2}{*}{$\begin{array}{c}\text { Pharmacokinetic } \\
\text { parameters }\end{array}$} & \multirow{2}{*}{ Units } & \multicolumn{2}{|c|}{ Mean \pm S.E. } \\
\hline V_F & ${\mathrm{ml} . \mathrm{kg}^{-1}}^{-1}$ & $5925.34 \pm 150.44$ & $5193.88 \pm 102.69$ \\
\hline $\mathrm{K}_{01}$ & $\mathrm{~h}^{-1}$ & $4.63 \pm 0.23$ & $3.99 \pm 0.22$ \\
\hline $\mathrm{K}_{10}$ & $\mathrm{~h}^{-1}$ & $0.23 \pm 0.01$ & $0.31 \pm 0.02$ \\
\hline $\mathrm{AUC}$ & $\mathrm{h} . \mu \mathrm{g} \cdot \mathrm{mL}^{-1}$ & $7.23 \pm 0.19$ & $6.42 \pm 0.34$ \\
\hline $\mathrm{K}_{01} \mathrm{HL}$ & $\mathrm{h}$ & $0.15 \pm 0.01$ & $0.18 \pm 0.01$ \\
\hline $\mathrm{K}_{10 \_} \mathrm{HL}$ & $\mathrm{h}$ & $2.97 \pm 0.11$ & $2.30 \pm 0.12$ \\
\hline $\mathrm{CL}_{-} \mathrm{F}$ & $\mathrm{ml} \cdot \mathrm{h}^{-1} \cdot \mathrm{kg}^{-1}$ & $1401.31 \pm 40.07$ & $1663.16 \pm 112.71$ \\
\hline $\mathrm{T}_{\max }$ & $\mathrm{h}$ & $0.69 \pm 0.02$ & $0.71 \pm 0.03$ \\
\hline $\mathrm{C}_{\max }$ & $\mu \mathrm{g} \cdot \mathrm{ml}^{-1}$ & $1.44 \pm 0.02$ & $1.55 \pm 0.03$ \\
\hline
\end{tabular}

Residual concentration ( $\left.\mu \mathrm{g} \cdot \mathrm{g}^{-1}\right)$ of levofloxacin in various tissues after $24 \mathrm{~h}$ following multiple (5) dose $\left(10 \mathrm{mg} \cdot \mathrm{kg}^{-1}\right)$ intramuscular administration in poultry $(\mathrm{n}=4)$

\begin{tabular}{|c|c|c|}
\hline Tissue & $24 \mathrm{~h}$ \\
\hline & 0.05 \\
\hline Liver & $0.14 \pm 0.03$ \\
\hline Kidney & $0.08 \pm 0.01$ \\
\hline Muscles & 0.00 \\
\hline
\end{tabular}

\begin{tabular}{|c|c|}
\hline Mean \pm S.E & \\
\hline $48 h$ & $72 h$ \\
\hline 0.04 & 0.02 \\
\hline $0.09 \pm 0.02$ & 0.04 \\
\hline 0.04 & 0.02 \\
\hline
\end{tabular}

The residual concentration of levofloxacin after $48 \mathrm{~h}$ post administration was found to be $0.09,0.04$ and $0.04 \mu \mathrm{g} . \mathrm{g}^{-1}$ in kidney, muscles and liver respectively. In kidney and muscle high concentration of levofloxacin was obtained than MRL of sarafloxacin in respective tissues i.e. 0.08 and $0.01 \mu \mathrm{g} \cdot \mathrm{g}^{-1}$ in kidney and muscles, respectively. After $72 \mathrm{~h}$ of drug withdrawal, the residual concentration of levofloxacin in kidney declined to $0.04 \mu \mathrm{g}$. $\mathrm{g}^{-1}$, whereas in liver and muscles equal tissue concentration of $0.02 \mu \mathrm{g}$. $\mathrm{g}^{-1}$ was observed. In liver $\left(0.02 \pm 0.00 \mu \mathrm{g} \cdot \mathrm{g}^{-1}\right)$, the concentration of levofloxacin was below maximum residual limit of sarafloxacin (0.08 $\mu \mathrm{g} . \mathrm{g}-1$; WHO, 1999). Levofloxacin could not be detected in liver, muscles and kidney after 96h post administration.

\section{References}

Amsden, G.W., Graci, D.M., Cabelus, L.J. and
Hejmanowski, L.G. (1999). A randomized, crossover design study of the pharmacology of extended-spectrum fluoroquinolones for pneumococcal infections. Chest. 116: 115-119

Chien, S.C., Chow, A.T. and Rogge, M.C. (1997). Pharmacokinetics and safety of oral levofloxacin in human immunodeficiency virus-infected individuals receiving concomitant zidovudine. Antimicrobial Agents and Chemotherapy. 41: 1765-1769

Chulavatnatol, S., Chindavijak, B., Vibhagool, A., Wananukul, W., Sriapha, C. and Sirisangtragul, C. (1999). Pharmacokinetics of levofloxacin in healthy Thai male volunteers. J. Med. Assoc. Thai. 82: 1127-1135.

Davis, R. and Bryson, H.M. (1994). Levofloxacin. A review of its antibacterial activity, pharmacokinetics and therapeutic efficacy. Drugs. 47 (4): 677-700.

Destache, C.J., Pakiz, C.B., Larsen, C., Owens, H. and Dash, A.K. (2001). Cerebrospinal 
fluid penetration and pharmacokinetics of levofloxacin in an experimental rabbit meningitis model. J. Antimicrobial Chemotherapy. 47: 611.

Edelstein, P. H., Edelstein, M. A., Lehr, K. H. and Ren, J. (1996). In vitro activity of levofloxacin against clinical isolates of Legionella spp., its pharmacokinetics in guinea pigs, and use in experimental Legionella pneumophila pneumonia. J. Antimicrob. Chemother. 37: 117-126.

Gascon, A.R., Campo, E., Hernandez, R.M., Calvo, B., Errasti, J. and Pedraz Munoz, J.L. (2000). Pharmacokinetics of ofloxacin enantiomers after intravenous administration for antibiotic prophylaxis in biliary surgery. J. Clinical Pharmacol. 40: 869-874.

Garcia-Ovando, H., Chlostri, L., Vania, A., Weyers, N., Biocomelli, R., Davicino and Gorla, N. (1997). HPLC residues of enrofloxacin and ciprofloxacin in eggs of laying hens. J. Vet. Pharmacol. Ther. 20: 181-182.

Ito, T., Yano, I., Masuda, S., Hashimoto, Y. and Inui, K. (1999). Distribution characteristics of levofloxacin and grepafloxacin in rat kidney. Pharmacological Research. 16: 534-539

Klesel, N., Geweniger, K. H., Koletzki, P., Isert, D., Limbert, M., Markus, A., Riess, G., Schramm, H. and Iyer, P. (1995): Chemotherapeutic activity of levofloxacin (HR355, DR-3355) against systemic and localized infections in laboratory animals. J. Antimicrobial Chemotherapy. 35(6): 805-819.
Langtry, H. D. and Lamb, H. M. (1998): Levofloxacin: its use in infections of the respiratory tract, skin, soft tissues and urinary tract. Drugs. 56: 487-515.

Mochizuki, K., Ohkubo, S., Torisaki, M., Yamashita, Y., Tanahashi, T., Jin, Y., Okamura, Y. and Tanaka, M. (1994). Intraoccular penetration of oral levofloxacin in rabbits. Nippon Ganka Gakkai Zasshi. 98: 1085-1090.

North, D. S., Fish, D.N. and Redington J. J. (1998): Levofloxacin, a second-generation fluoroquinolone. Pharmacotherapy. 18: 915-935.

Telling, G.M. and Sissons, D.J. (1977). Determination of OCs residues in fatty food stuffs using a clean up technique based on a single column of activated Alumina. J. Chromatography. 137: 405423.

Verho, M., Malerczyk, V., Damm, D. and Lehr, K.H. (1996). Pharmacokinetics of levofloxacin in comparison to the racemic mixture of ofloxacin in man. Drug Metabolism and Drug Interactions. 13: 57-67.

WHO Technical Series (1999). Evaluation of certain veterinary drug residues in food. Fiftieth report of the Joint FAO/WHO Expert Committee on Food additives. pp: 33-39.

WHO Technical Series. (2006). Evaluation of certain veterinary drug residues in food. Sixty-sixth report of the Joint FAO/WHO Expert Committee on Food additives. pp: 45-47.

\section{How to cite this article:}

Preeti Bisht, A.H. Ahmad, Alok Mishra and Sankalp Sharma. 2018. Pharmacokinetics and Tissue Residue Study of Levofloxacin Following Multiple Dose Intramuscular Administration in Poultry. Int.J.Curr.Microbiol.App.Sci. 7(07): 2614-2618.

doi: https://doi.org/10.20546/ijcmas.2018.707.306 